\title{
Comparison of Turkey and European Countries According to Basic Health Indicators
}

\section{Temel Sağlık Düzeyi Göstergeleri Açısından Türkiye ve Avrupa Birliği Ülkeleri}

\author{
Selçuk Serdar Köksal ${ }^{1}$, Nurver Turfaner Sipahioğlu $*^{2}$, Eray Yurtsever ${ }^{1}$, Suphi Vehid ${ }^{2}$
}

\begin{abstract}
Objectives:European Union (EU) is a political and financial organization consisting of 28 countries. Turkey is a candidate country for the EU. In this study, Turkey and EU countries are compared according to 15 basic health level indicators.Expectancy of life at birth, gross national product (GNP) per capita, health expenditure per capita, share of health in national budget, population growth rate, literacy rate, infant mortality rate, under-five mortality rate, maternal mortality rate, crude birth rate, crude mortality rate, total fertility rate, physicians, nurses and number of beds per 10000 people are evaluated.Method:The data are based on The World Bank records of 1960, 1970, 1980, 1990 and 2013. Packaged software MS Excel 2010 and SPSS ver.21 are used for statistical analysis. Results:Turkey is different in terms of population growth rate, crude birth rate and fertility rate from EU countries, and this situation results in an excess of dependent young population affecting economy negatively. Gross national product per capita is only higher than Bulgaria and the share of health from general budget and health expenditure per capita is lower than EU average. Although infant mortality rate and mortality rate under-five have displayed a fast decrease since 1960, 2013 values are still higher than EU countries. Maternal mortality rate decreased over the years to be less than Romania (0.00027), and equal to Letonia (0.00020). Crude mortality rate was found less than EU countries. The reason may be attributed to the younger population of Turkey. The human resources in health field is less than EU. Conclusion:Improving maternal and infant health, increasing the share of health from the national budget and better planning of human resources may help Turkey to get closer to EU averages of basic health level indicators.
\end{abstract}

Key words: Health level indicators, European Union, Turkey

\section{ÖZET}

Amaç:Avrupa Birliği (AB), yirmi sekiz ülkeden oluşan siyasi ve ekonomik bir örgütlenmedir. Türkiye, Avrupa birliğine aday ülkeler arasında yer almaktadır. Ülkelerin sağlık düzeylerinin değerlendirilmesi ve karşılaştırmaları için çeşitli sağlık düzeyi göstergeleri kullanılmaktadır. Bu çalışmada, Türkiye ve diğer Avrupa Birliği ülkeleri, 15 temel sağlık düzeyi göstergesi açısından karşılaştırılmıştır. Temel sağlık düzeyi göstergelerinden, doğumda yaşam ümidi, kişi başı gayri safi milli hasıla, kişi başı sağlık harcaması, genel bütçeden sağlık payı, nüfus artış hızı, okuryazarlık oranı, bebek ölüm hızı, beş yaş altı ölüm hızı, anne ölüm hızı, kaba doğum hızı, kaba ölüm hızı, toplam doğurganlık hızı, on bin kişiye düşen hekim, hemşire, ebe ve yatak sayısı değerlendirilmiştir. Yöntem: Verilerin elde edilmesi için 1960, 1970, 1980, 1990 ve 2013 yılı Dünya Bankası kayıtları esas alınmıştır. İstatistiksel analiz için MS Excel 2010 ve SPSS ver.21 (İstanbul Üniversitesi Lisanslı) paket programları kullanılmıştır. Bulgular:Türkiye'de nüfus artış hızı, kaba doğum hızı ve doğurganlık hızı Avrupa Birliği ülkelerinden fazladır. Bu durum üretken olmayan genç nüfusun fazla olup, ekonomi üzerinde olumsuz etkiler oluşturmasına yol açmaktadır. Türkiye'de kişi başı düşen milli gelir sadece Bulgaristan'dan yüksektir. Genel bütçeden sağlık için harcanan pay ve kişi başı sağlık harcaması, Avrupa Birliği ortalamalarından daha düşüktür. Bebek ölüm hızı ve beş yaş altı ölüm hızında 1960'dan itibaren hızlı bir azalma gözlenmesine rağmen, 2013 yılı değerleri Avrupa Birliği ülkelerinden yüksektir. Anne ölüm hızı, yıllar içinde azalarak Romanya'dan daha düşük (yüzbinde 27), Letonya (yüzbinde 20) ile eşdeğer düzeye gelmiştir. Kaba ölüm hızı, AB ülkelerinden daha düşük olarak bulunmuştur, bunun nedeni ülkemiz nüfusunun daha genç olması olabilir. Sağlık alanında çalışan insan gücü açısından, ülkemiz sonuçları AB'den daha geridedir. Sonuç:Türkiye'de ana-çocuk sağlı̆̆ı hizmetlerinin geliştirilmesi, milli gelirden sağlığa ayrılan payın arttırılması ve sağlık alanında insan gücü planlamasının iyileştirilmesi ile Avrupa Birliği’nin sağlık düzeyi göstergelerinin ortalamasına yaklaşmak mümkün olabilir.

Anahtar kelimeler: Sağlık düzeyi göstergeleri, Avrupa Birliği, Türkiye

Received / Geliş tarihi: 23.11.2015, Accepted / Kabul tarihi: 11.10.2016

${ }^{1}$ İstanbul Üniversitesi Cerrahpaşa Tıp Fakültesi Halk Sağlığı Anabilim Dalı

${ }^{2}$ İstanbul Üniversitesi Cerrahpaşa Tıp Fakültesi Aile Hekimliği Anabilim Dalı

*Address for Correspondence / Yazışma Adresi: Nurver Turfaner Sipahioğlu, İstanbul Üniversitesi Cerrahpaşa Tıp Fakültesi Aile Hekimliği Anabilim Dalı, İstanbul-TÜRKIYE, E-mail: nurverdi@gmail.com

Köksal SS, Sipahioğlu NT, Yurtsever E, Vehid S. Temel Sağlık Düzeyi Göstergeleri Açısından Türkiye ve Avrupa Birliği Ülkeleri, TJFMPC, 2016;10(4):

205-212. DOI: 10.21763/tjfmpc.271087 


\section{GíRIŞ}

Avrupa Birliği (AB), yirmi sekiz üye ülkeden oluşan ve toprakları büyük ölçüde Avrupa kıtasında bulunan siyasi ve ekonomik bir örgütlenmedir. Günümüz itibarı ile Avrupa Birliğine üye devletler Almanya, Avusturya, Belçika, Bulgaristan, Çekoslovakya, Danimarka, Estonya, Finlandiya, Fransa, Hollanda, İngiltere İrlanda, İspanya, İsveç, İtalya, Kıbrıs, Letonya, Litvanya, Lüksemburg, Macaristan, Malta, Polonya, Portekiz, Romanya, Slovakya, Slovenya, Yunanistan ve Hırvatistan'dır. Türkiye, Sirbistan ve Makedonya ile birlikte Avrupa Birliği'ne aday ülkeler arasında yer almaktadır.

Türkiye, Avrupa Birliği’ne tam üyelik için gereken siyasi, demokratik, ekonomik ve diğer koşulların yanı sıra sağlık koşullarını da belli bir düzeye getirme çalışmalarını sürdürmektedir.

Ülkelerin sağl1k düzeylerinin saptanması ve değerlendirilmesi ile ülkeler arası karşılaştırmalar için, çeşitli epidemiyolojik sağlık düzeyi ölçütleri bulunmaktadır. Bu ölçütlerin en sık kullanılanları ölüm, hastalık, doğurganlık oranları ve sosyo-ekonomik durum başlıkları altında toplanabilir:

Çalışma kapsamına alınan, temel sağlık düzeyi göstergelerinden "doğumda yaşam ümidi”; bir toplumda yeni doğan bir kişinin ortalama kaç yıl yaşayacağını belirten bir ölçüt olup yıl olarak, "kişi başı gayri safi milli hasıla"; bir toplumun bir yıl için ürettiği toplam mal ve hizmetlerinin, belli bir para birimi karşılığındaki değerinin toplamının nüfus sayısına bölümü olup para birimi olarak, "kişi başı sağlık harcaması”; bir toplumda bir yıl içinde sağlık için harcanan toplam para miktarının nüfus sayısına bölümü olup para birimi olarak, "genel bütçede sağlık payı"; bir toplumda genel bütçe içinde sağlığa ayrılan pay olup \% olarak, "kaba doğum hızı"; bir toplumda belli bir zaman sürecinde meydana gelen canlı doğum sayısının aynı toplumun aynı süre içindeki nüfus sayısına bölümü olup \%o (binde) olarak, "kaba ölüm hızı"; bir toplumda belli bir zaman süresinde meydana gelen toplam ölüm sayısının aynı toplumun aynı süre içindeki nüfus sayısına bölümü olup \%o (binde) olarak, "genel doğurganlık hızı"; bir toplumda belli bir zaman süresinde meydana gelen toplam canlı doğum sayısının aynı toplumda aynı sürede ki doğurgan çağda (15-44 yaş veya 15-49 yaş) kadın nüfus sayısına bölümü olup \%o (binde) olarak, "bebek ölüm hızı"; belli bir zaman periyodunda bir toplumda canlı doğan ve bir yaşını doldurmadan ölen bebeklerin sayısının aynı toplumda aynı süre içindeki canlı doğum sayısına bölümü olup \%o (binde) olarak, "beş yaş altı ölüm hızı"; belli bir zaman periyodunda bir toplumda canlı doğan ve beş yaşını doldurmadan ölen bebeklerin sayısının aynı toplumda aynı süre içindeki canlı doğum sayısına bölümü olup \%o (binde) olarak, "anne ölüm hızı"; bir toplumda belli bir zaman süresinde, gebelik sırasında, doğum esnasında ve doğumdan sonraki ilk 6 hafta içinde ölen kadın sayısının aynı toplumda aynı süredeki canlı doğum sayısına bölümü olup \% (yüz binde) olarak, "kişi başına düşen sağlık personeli/hastane yatak sayısı"; bir toplumda belli bir zamanda ki nüfus sayısının aynı zaman süresinde mevcut sağlık personeli/hastane yatak sayısına bölümü olup binde, (onbinde) olarak tanımlanmaktadır.

$\mathrm{Bu}$ çalışmada, Avrupa Birliği üyeliğine aday olan Türkiye ile diğer Avrupa Birliği üyesi ülkelerin temel sağlı düzeyi göstergelerinin karşılaştırması yapılarak, Türkiye'nin Avrupa Birliği ülkeleri içerisindeki durumu irdelenmiştir.

\section{MATERYAL METOD}

Türkiye ve 28 Avrupa Birliği ülkesine ait temel sağlık düzeyi göstergelerinden; doğumda yaşam ümidi, kişi başı gayri safi milli hasıla (GSMH), kişi başı sağlık harcaması, genel bütçeden ayrılan sağlık payı, nüfus artış hızı, okuryazarlık oranı, bebek ölüm hızı, beş yaş altı ölüm hızı, anne ölüm hızı, kaba doğum hızı, kaba ölüm hızı, toplam doğurganlık hızı, on bin kişiye düşen hekim, hemşire-ebe ve yatak sayısı olmak üzere toplam 15 gösterge çalışma kapsamında değerlendirilmiştir. Türkiye ve $A B$ ülkelerinin sağlik düzeyi göstergelerine ait ham veriler, tüm ülkelerin verilerinin eksiksiz yer aldığ Dünya Sağlık Örgütü (DSÖ) ve Dünya Bankası istatistiklerinden alınmıştır. Türkiye sağlık istatistik yıllığı(TUİK) verilerinden de yararlanılmıştır. Doğumda yaşam ümidi, kaba doğum hızı, kaba ölüm hızı, nüfus artış hızı, toplam doğurganlık hızı, bebek ölüm hızı, beş yaş altı ölüm hızı, kişi başı gayri safi milli hasıla, anne ölüm hızı, on bin kişiye düşen doktor, hemşire-ebe ve hastane yatak sayısı için 2013 yılı, genel bütçeden ayrılan sağlık payı, kişi başı sağlık harcaması ve okuryazarlık oranı için 2012 yılı verileri esas olarak alınmıştır. ${ }^{5-9}$ Avrupa Birliği ülkeleri ile Türkiye'nin temel sağlık düzeyi göstergelerinin 1960, 1970, 1980, 1990 ve 2000 ve 2013 yılı verileri için Dünya Bankası, Dünya Sağlık Örgütü ve UNICEF kayıtlarından yararlanılmıştır. ${ }^{5,7,9}$

Avrupa Birliği ülkelerine ait ham verilerden, Avrupa Birliği ülkelerinin merkezi dağılım ölçütleri elde edilmiştir. Avrupa Birliği ülkelerinin temel sağlık düzeyi göstergeleri ortalamaları ile, Türkiye'nin temel sağlık düzeyi gösterge değerleri tek örneklem $t$ testi ile karşılaştırılarak istatistiksel olarak anlamlı bir fark olup olmadığı incelenmiştir.

Diğer taraftan AB ülkeleri ile, Türkiye'nin temel sağlık düzeyi göstergelerinin 1960-2009 yılları arasında on yıllar içinde ki durumu 
araştırılmıştır. Ham verilerin analizi ve istatistik analizler için, MS Excel 2010 ve SPSS Ver.21 (İstanbul Üniversitesi Lisansl1) paket programları kullanılmıştır.

\section{BULGULAR}

Avrupa Birliği ülkeleri toplam nüfusu, 2013 yılı verilerine göre 505.180.000 olup, nüfusun \%16,6's1
15 yaş altında, \% 15,6'sı ise 65 yaş üstündedir. Aynı yılda, Türkiye nüfusu 74.933 .000 olup, Türkiye nüfusunun $\% 26,8$ 'i 15 yaş altında, \%5,9'u ise 65 yaş üstünde bulunmaktadır. ${ }^{7,9} 2013$ yılı verilerine göre, $\mathrm{AB}$ ülkeleri nüfus artış hızı ortalaması \%0,3 iken, Türkiye için nüfus artış hızı $\% 1,3$ olup, nüfus artış hızları arasında istatistiksel olarak anlamlı farklılık bulunmaktadır (Tablo 1).

\begin{tabular}{|c|c|c|c|c|c|}
\hline Gösterge & $\underline{\text { Yll }}$ & $\begin{array}{l}\text { Türkiye } \\
\text { (değer) }\end{array}$ & $\begin{array}{c}\text { Avrupa Birliği } \\
\text { Ülkeleri } \\
\text { (ortalama) }\end{array}$ & & \\
\hline & & & Ort \pm SD & Min-Max & $\mathbf{p}$ \\
\hline $\begin{array}{c}\text { Doğumda yaşam ümidi } \\
(\text { y1l })\end{array}$ & 2013 & 75 & $79,3 \pm 2,9$ & $74-83$ & $p<0,001$ \\
\hline Kişi başı gayri safi milli hasıla (USD) & 2013 & 18783 & $32743 \pm 9129$ & $15732-46162$ & $p<0,001$ \\
\hline $\begin{array}{l}\text { Nüfus artış hızı } \\
(\%)\end{array}$ & 2013 & 1,3 & $0,3 \pm 0,6$ & $-1,1-1,7$ & $p<0,001$ \\
\hline $\begin{array}{c}\text { Okuryazarlık oran } 1 \\
(\%)\end{array}$ & 2012 & 94 & $98,4 \pm 1,7$ & $91,6-100,0$ & $p<0,001$ \\
\hline $\begin{array}{l}\text { Bebek ölüm hiz1 } \\
\text { (binde) }\end{array}$ & 2013 & 16,5 & $4,1 \pm 2,1$ & $1,6-10,5$ & $p<0,001$ \\
\hline $\begin{array}{l}\text { Beş yaş alt1 ölüm hızı } \\
\text { (binde) }\end{array}$ & 2013 & 19,2 & $4,8 \pm 2,4$ & $2,0-12,0$ & $p<0,001$ \\
\hline $\begin{array}{l}\text { Anne ölüm hızı } \\
\text { (yüzbinde) }\end{array}$ & 2013 & 20,0 & $8,0 \pm 5,8$ & $3,0-33,0$ & $p<0,001$ \\
\hline $\begin{array}{l}\text { Kaba doğum hızı } \\
\text { (binde) }\end{array}$ & 2013 & 16,8 & $10,7 \pm 1,4$ & $8,5-15,4$ & $p<0,001$ \\
\hline $\begin{array}{l}\text { Kaba ölüm hızı } \\
\text { (binde) }\end{array}$ & 2013 & 5,7 & $9,7 \pm 2,1$ & $5,5-14,2$ & $p<0,001$ \\
\hline $\begin{array}{l}\text { Toplam doğurganlık hızı } \\
\text { (binde) }\end{array}$ & 2013 & 2,0 & $1,6 \pm 0,2$ & $1,3-2,0$ & $p<0,001$ \\
\hline $\begin{array}{l}\text { Genel bütçede sağlık payı } \\
(\%)\end{array}$ & 2012 & 5,4 & $8,8 \pm 1,8$ & $5,6-12,7$ & $p<0,001$ \\
\hline $\begin{array}{l}\text { Kişi başı sağlık harcaması } \\
\text { (USD) }\end{array}$ & 2012 & 569 & $2973 \pm 2013$ & $468-7551$ & $p<0,001$ \\
\hline $\begin{array}{c}\text { Hekim } \\
\text { (10000 nüfus başına) }\end{array}$ & 2013 & 17,1 & $34,7 \pm 8,5$ & $22,2-60,0$ & $p<0,001$ \\
\hline $\begin{array}{c}\text { Hemşire } \\
\text { (10000 nüfus başına) }\end{array}$ & 2013 & 24,0 & $79,9 \pm 34,3$ & $34,4-167,9$ & $p<0,001$ \\
\hline $\begin{array}{c}\text { Hastane yatağı } \\
\text { (10000 nüfus başına) }\end{array}$ & 2013 & 15,0 & $52,5 \pm 16,1$ & $27,0-82,0$ & $p<0,001$ \\
\hline
\end{tabular}




\begin{tabular}{|c|c|c|c|c|c|c|}
\hline Temel Sağlık Göstergesi & 1960 & 1970 & 1980 & 1990 & 2000 & 2013 \\
\hline $\begin{array}{l}\text { Doğumda yaşam ümidi (y1l) } \\
\text { Avrupa Birliği Ülkeleri (Ort) } \\
\text { Türkiye }\end{array}$ & $\begin{array}{l}69,3 \\
50\end{array}$ & $\begin{array}{l}70,8 \\
55\end{array}$ & $\begin{array}{l}72,3 \\
60\end{array}$ & $\begin{array}{l}73,9 \\
65\end{array}$ & $\begin{array}{l}75,9 \\
69\end{array}$ & $\begin{array}{l}79,3 \\
75,0\end{array}$ \\
\hline $\begin{array}{l}\text { Kişi başı gayri milli hasıla (USD } \\
\text { Avrupa Birliği Ülkeleri (Ort) } \\
\text { Türkiye }\end{array}$ & $\begin{array}{l}1064 \\
495\end{array}$ & $\begin{array}{l}2230 \\
472\end{array}$ & $\begin{array}{l}8847 \\
1490\end{array}$ & $\begin{array}{l}12967 \\
2687\end{array}$ & $\begin{array}{l}15458 \\
4010\end{array}$ & $\begin{array}{l}32743 \\
18783\end{array}$ \\
\hline $\begin{array}{l}\text { Nüfus artış hızı (yüzde) } \\
\text { Avrupa Birliği Ülkeleri (Ort) } \\
\text { Türkiye }\end{array}$ & $\begin{array}{l}0,8 \\
2,6\end{array}$ & $\begin{array}{l}0,2 \\
2,5\end{array}$ & $\begin{array}{l}0,5 \\
2,2\end{array}$ & $\begin{array}{l}0,2 \\
1,7\end{array}$ & $\begin{array}{l}0,2 \\
1,5\end{array}$ & $\begin{array}{l}0,3 \\
1,3\end{array}$ \\
\hline $\begin{array}{l}\text { Bebek ölüm hızı (binde) } \\
\text { Avrupa Birliği Ülkeleri (Ort) } \\
\text { Türkiye }\end{array}$ & $\begin{array}{l}34,7 \\
162\end{array}$ & $\begin{array}{l}24,1 \\
150\end{array}$ & $\begin{array}{l}15,1 \\
105\end{array}$ & $\begin{array}{l}10,1 \\
69\end{array}$ & $\begin{array}{l}6,5 \\
36\end{array}$ & $\begin{array}{l}4,1 \\
16,5\end{array}$ \\
\hline $\begin{array}{l}\text { Beş yaş altı ölüm hızı (binde) } \\
\text { Avrupa Birliği Ülkeleri (Ort) } \\
\text { Türkiye }\end{array}$ & $\begin{array}{l}41,6 \\
218\end{array}$ & $\begin{array}{l}28,1 \\
200\end{array}$ & $\begin{array}{l}17,6 \\
137\end{array}$ & $\begin{array}{l}12,2 \\
84\end{array}$ & $\begin{array}{l}7,9 \\
42\end{array}$ & $\begin{array}{l}4,8 \\
19,2\end{array}$ \\
\hline $\begin{array}{l}\text { Kaba doğum hızı (binde) } \\
\text { Avrupa Birliği Ülkeleri (Ort) } \\
\text { Türkiye }\end{array}$ & $\begin{array}{l}18,9 \\
46\end{array}$ & $\begin{array}{l}16,5 \\
39\end{array}$ & $\begin{array}{l}14,9 \\
33\end{array}$ & $\begin{array}{l}13,1 \\
26\end{array}$ & $\begin{array}{l}10,7 \\
21\end{array}$ & $\begin{array}{l}10,7 \\
16,8\end{array}$ \\
\hline $\begin{array}{l}\text { Kaba ölüm hızı (binde) } \\
\text { Avrupa Birliği Ülkeleri (Ort) } \\
\text { Türkiye }\end{array}$ & $\begin{array}{l}9,9 \\
18\end{array}$ & $\begin{array}{l}10,3 \\
12\end{array}$ & $\begin{array}{l}10,5 \\
10\end{array}$ & $\begin{array}{l}10,5 \\
8\end{array}$ & $\begin{array}{l}10,2 \\
6\end{array}$ & $\begin{array}{l}9,7 \\
5,7\end{array}$ \\
\hline $\begin{array}{l}\text { Toplam doğurganlık hızı (binde) } \\
\text { Avrupa Birliği Ülkeleri (Ort) } \\
\text { Türkiye }\end{array}$ & $\begin{array}{l}2,6 \\
6,3\end{array}$ & $\begin{array}{l}2,3 \\
5,6\end{array}$ & $\begin{array}{l}1,9 \\
4,4\end{array}$ & $\begin{array}{l}1,7 \\
3,1\end{array}$ & $\begin{array}{l}1,6 \\
2,3\end{array}$ & $\begin{array}{l}1,6 \\
2.0\end{array}$ \\
\hline
\end{tabular}

Temel sağlık göstergelerinin en önemlilerinden, doğumda yaşam ümidi Türkiye'de 75 yıl iken, $\mathrm{AB}$ ülkeleri ortalaması 79,2 yıldır. USD olarak kişi başına düşen GSMH Türkiye'de 18783 USD olmasına karşın, bu değer AB ülkeleri için ortalama 32743 USD olarak hesaplanmıştır. Yine önemli bir ölçüt olan okuryazarlık oranı, Türkiye'de \% 94 olmasına karşın, bu ölçüt $\mathrm{AB}$ ülkelerinde ortalama \% 98,4 olarak hesaplanmıştır. Doğumda yaşam ümidi, kişi başı GSMH ve okuryazarlık oranları değerleri açısından Türkiye ve $\mathrm{AB}$ ülkeleri arasında istatistiksel olarak anlamlı farklılık saptanmıştır $(\mathrm{p}<0,001)$ (Tablo1). Diğer yandan, doğumda yaşam ümidinin zaman içindeki değişimi incelendiğinde Türkiye ve $\mathrm{AB}$ ülkeleri açısından yıllar içinde artış söz konusu olduğu halde, aralarında istatistiksel olarak anlamlı farklılığın devam ettiği görülmektedir. $(p<0,001)$ (Tablo2). değerlendirilmesinde kullanılan en önemli ölçütler olan bebek ölüm hızı ve beş yaş altı ölüm hızı açısından Türkiye ve $\mathrm{AB}$ ülkeleri karşılaştıııldı̆̆ında, bebek ölüm hızı Türkiye için binde 16,5 (TUiK verilerine göre 2012 y1linda binde 11,6, 2013 yllinda binde10,8) iken, $\mathrm{AB}$ ülkeleri ortalaması binde 4,1 düzeyindedir. Beş yaş altı ölüm hızı ise, Türkiye'de binde 19,2 olmasına karşın (TUiK verilerine göre 2013'te binde 13,4, 2014'te binde 13,3) AB ülkelerinde bu ölçüt ortalaması binde 4,8 dir. ${ }^{10}$ Bu ölçütler açısından Türkiye ve $A B$ ülkeleri ortalama değeri arasında, çok ileri derecede istatistiksel anlamlı farkl11ık bulunmakta olup; bu ölçütlerin yıllar içindeki değişimi incelendiğinde, her iki değerde de düşüş saptanmasına rağmen, Türkiye ve $A B$ ülkeleri arasındaki istatistiksel olarak anlamlı farklılığın belirgin olarak devam ettiği tespit edilmiştir ( $\mathrm{p}<0,001)$ (Tablo 2).

Ülkelerin, sağlık durumlarının 


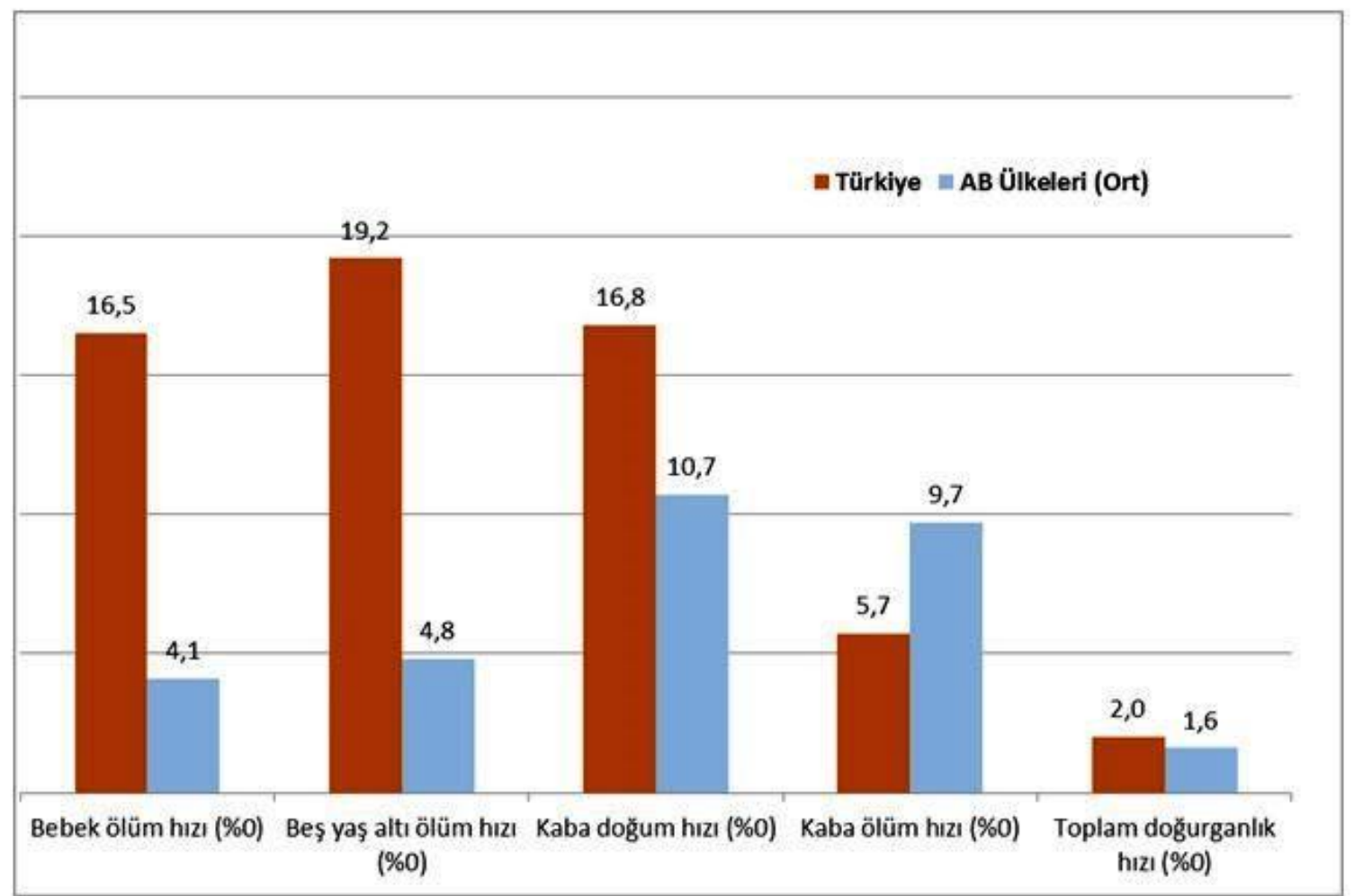

Şekil 1. Türkiye ve Avrupa Birliği Ülkelerinde Temel Demografik Göstergeler

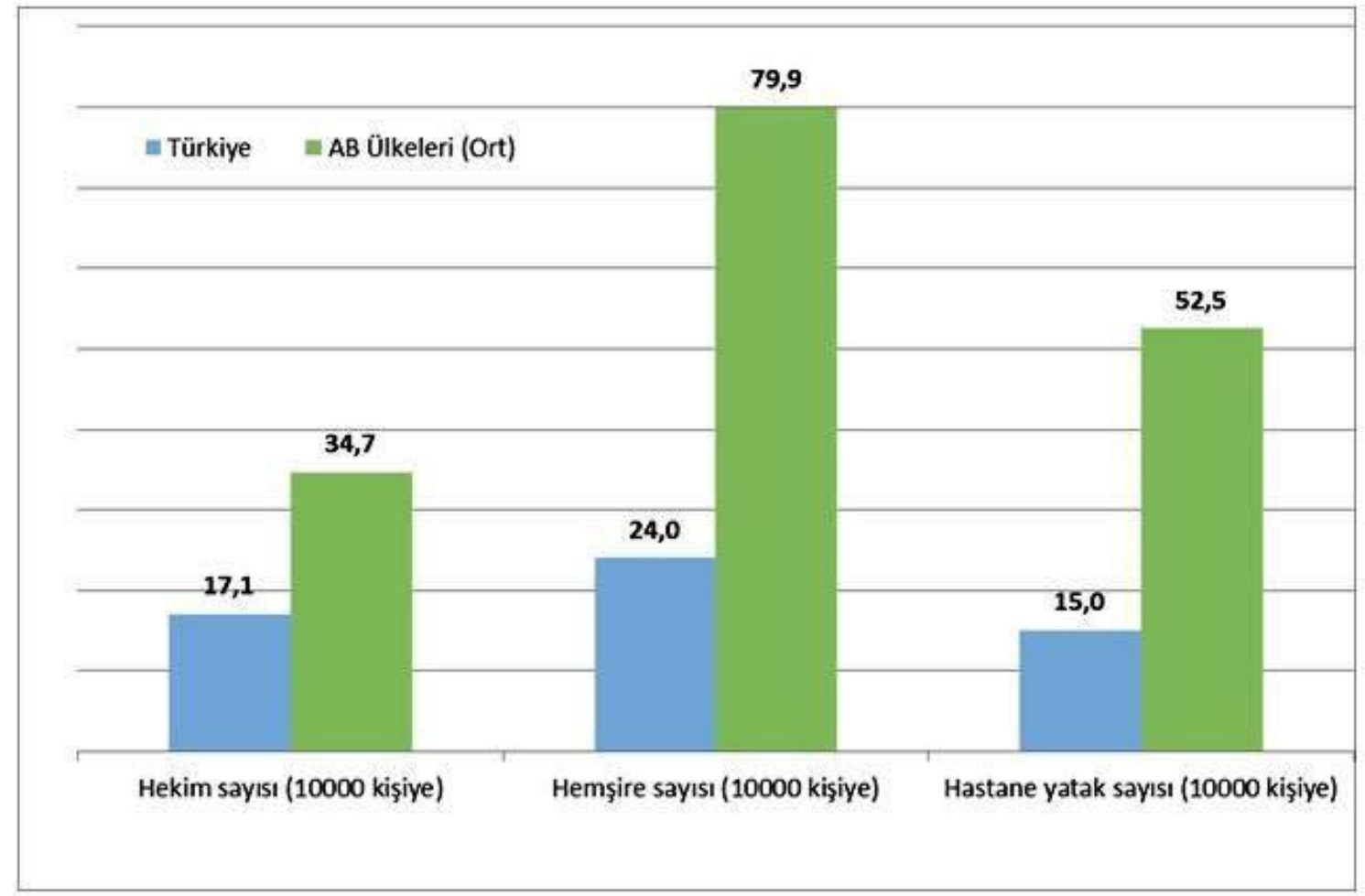

Şekil 2. Türkiye ve Avrupa Birliği Ülkelerinde On nbin Kişiye Düsşen Sağlık Personeli ve Yatak Sayısı 
Tablo 1 de temel demografik göstergeler incelendiğinde; Türkiye ve AB ülkeleri ortalaması kaba doğum hızı için binde 16,8 ve binde 10,7 , kaba ölüm hızı için binde 5,7 ve binde 9,7 , toplam doğurganlık hızı için ise binde 2,0 ve binde 1,6 dir (Tablo 1), (Şekil 1). Temel demografik göstergelerin yıllar içindeki değişimi incelendiğinde her ne kadar Türkiye verilerinde belirgin iyileşme saptansa da, $A B$ ülkeleri ile arasında göstergeler açısından belirgin farklılıklar sürmektedir ( $\mathrm{p}<0,001)$ (Tablo 2).

Türkiye ve $\mathrm{AB}$ ülkelerinde genel bütçeden sağlık için ayrılan pay incelendiğinde; bu pay Türkiye'de \%5,4 olmasına karşın, AB ülkeleri ortalaması $\% 8,8$ olarak hesaplanmıştır. Yine sağlığın ekonomik boyutunu gösteren kişi başına sağlık harcaması, Türkiye'de 569 USD iken, AB ülkeleri ortalaması 2973 USD olarak hesaplanmıştır $(\mathrm{p}<0,001)$ (Tablo 1).

Temel sağlık düzeyi göstergeleri içinde yer alan, sağlıkta insan gücü ve hastane yatak durumunu gösteren ölçütlerden; on bin kişiye düşen hekim sayısı Türkiye'de 17,1 iken, AB ülkelerinde ortalama $34,7^{\prime}$ 'dir. On bin kişiye düşen hemşire -ebe sayısı Türkiye'de 24 iken AB ülkeleri ortalaması 79,9' dur. On bin kişiye düşen hastane yatak sayısı ise Türkiye'de 15 olmasına karşın AB ülkeleri ortalaması 52,5 yatak olarak hesaplanmıştır. On bin kişiye düşen hekim, hemşire-ebe ve hastane yatak sayısı açısından Türkiye ve $A B$ ülkeleri ortalama değerleri arasında istatistiksel olarak çok ileri derecede anlamlı farklılık bulunmaktadır $(\mathrm{p}<0.001)$ (Tablo 1), (Şekil 2).

\section{TARTIȘMA}

Türkiye, 1950'lerin sonuna kadar nüfus artışını doğrudan veya dolaylı yollarla teşvik etmiştir. Ancak denetim mekanizmaları doğru yapılanamadığından, gebelik ve lohusalık dönemlerinde artan komplikasyonlara ve bunun sonucu olarak anne ölümlerinde artışa neden olmuştur. ${ }^{3}$ Sonraki yıllarda nüfus planlaması konusunda organize yaklaşımlar sonucu ana çocuk sağlığı hizmetlerinin geliştirilmesine önem verilmiştir. Planlı, dengeli ve sürdürülebilir kalkınma hedefi ile uyumlu bir nüfus yapısına ulaşmak amacıyla toplumun eğitim, sağlık ve insan gücü yönünden niteliklerinin iyileştirilmesi ve yaşam kalitesinin yükseltilmesine yönelik nüfus politikaları oluşturulmaya başlanmıştır. ${ }^{1,2}$ Bunun sonucunda temel sağlık düzeyi göstergelerinde hılı bir iyileşme olduğu gözlenmiştir. 1960 yılında Türkiye'nin nüfus artış hızı \%2,6 iken AB ülkeleri ortalaması \%0,8' dir.
Türkiye, AB'ye üye ülkeler arasında Almanya'dan sonra en fazla nüfusa sahip olan ülkedir. 2013 y1lı verilerine göre, 74.933 .000 kişi olan Türkiye nüfusunun \%27'si genç bağımlı, üretken olmayıp, tüketici durumda olan nüfus olarak karşımıza çıkmaktadır. Almanya için bu değer \%14 düzeyindedir. Kaba doğum hızı ve toplam doğurganlık hızları açısından değerlendirme yaptığımızda, söz konusu göstergelerin, ülkemiz açısından $\mathrm{AB}$ topluluğuna üye ülkeler ortalamasindan istatistikse 1 olarak anlamlı şekilde yüksek olduğu belirlenmiştir $(p<0,001)$. $\mathrm{Bu}$ durumun ülkemizdeki tüketi ci durumda, bağımlı nüfusun fazla olmasına ve ekonomi üzerinde olumsuz etkilere yol açabileceği düşünülmektedir. ${ }^{9}$ Ülkemizde kişi başına GSMH 18760 US dolar iken, AB ortalamas1 30848 US dolardır. AB'ye üye tüm ülkeler değerlendirildiğinde, ülkemizin sadece Bulgaristan'dan daha yüksek kişi başı GSMY'ye sahip olduğu saptanmıştır. Diğer taraftan, Türkiye'de GSMH'dan sağlık için harcanan pay $\%$ 5,4 ile Avrupa Birliğini oluşturan ülkelerin oransal olarak çok gerisinde kalmaktadır. Bu değer, Bulgaristan için \%7,3 tür. Yapılan değerlendirme sonucunda kişi başı GSMH (USD), genel bütçeden ayrılan sağlık payı ve kişi başı sağlık harcamaları açısından ülkemiz ortalamasının $\mathrm{AB}$ ortalamalarından istatistiksel olarak anlaml şekilde düşük olduğu belirlenmiştir $(p<0,001)$. Gelir düzeyinin ve beraberinde sağllğa ayrılan payın düşük olmasından, sağlık hizmetlerinin ve özellikle temel sağlık hizmetlerinin kötü yönde etkilenmesi kaçınılmazdır. ${ }^{3} \mathrm{Bu}$ açıdan, AB'ye üyelik talebinde bulunan ülkemizin, genel bütçeden artan oranlarda sağlığa pay ayırması gerekmektedir. ${ }^{2}$ Sağlık düzeyi ölçütlerinden doğumda yaşam ümidi süresinin, Türkiye açısından hızlı bir iyileşme gösterdiği, 1960 y1lından itibaren yükselen bir grafik ile 2013 yılında 75 yıla kadar çıktığı belirlenmiştir. Bu süre, 1960 yılında Türkiye için 50 iken, AB ortalaması 69,3 olarak görülmektedir. Her geçen yıl Türkiye ve $A B$ arasındaki fark kapanmasına rağmen, 2013 yılı verileri karşılaştırıldığında, Türkiye'nin doğumda yaşam ümidi süresi $A B$ 'ye üye ülkelerden istatistiksel olarak anlamlı düzeyde geridedir $(p<0,001)$. AB ortalaması göz önüne alındığında, Türkiye'nin 1980'li yıllardaki süreye daha yeni ulaştığı anlaşılmaktadır.

Sağlık programlarının izlenmesi, değerlendirilmesi ve ileriye yönelik politikaların belirlenmesi açısından bebek ölüm hızları ve beş yaş altı ölüm hızları önem taşımaktadır. Çalışmamızda ulaşılan önemli sonuçlardan biri de, bebek ölüm hızlarının 1960'dan itibaren ülkemizde hızlı bir düşüş göstermiş olmasına karşın, 2013 yılı itibariyle, $\mathrm{AB}$ ülkeleri ortalamasından istatistiksel olarak anlamlı şekilde yüksek olduğudur $(p<0,001)$. 
Üye ülkelerden en yüksek bebek ölüm hızı, Romanya'da binde 10 olmasına karşın, ülkemizde bu değerin binde 16,5 gibi daha yüksek bir değerde olduğu gözlenmektedir. Benzer şekilde, beş yaş altı bebek ölümleri ortalamasının $\mathrm{AB}$ ortalamasından istatistiksel olarak anlamlı düzeyde yüksek olduğu görülmektedir. Bu değerler Romanya için binde 12, Bulgaristan için binde 10 ve ülkemiz için binde19,2 (TUIK verilerine göre 2013'te binde 13,4, 2014'te binde 13,3) düzeyindedir. Araştırmamızda bu ölüm hızlarını etkileyebilecek nedenler arasında yer alan bağışıklama oranları o yıllar için değerlendirilmemiş olmasına karşın Vehid'in yapmış olduğu çalışmada, bağışıklamanın düşük olması nedeniyle bebek ve beş yaş altı ölümlerin ülkemizde yüksek olduğu belirtilmektedir12. Son 5 yılda TUIK verilerine göre aşılama oranlarımızın yüksek olduğu (BCG/\%95) göz önüne alındığında, annelerin bebek ve çocuk beslenmesi ve bakımı konusunda eğitim eksikliği ve s1k aralıklarla iyileştirilmesi ile doğumların sağlık kuruluşlarında gerçekleşmesinin anne ölüm hızını daha da aşağıllara çekeceği düşünülmektedir. ${ }^{13}$

Araştırmamızda, kaba ölüm hızımız AB ülkelerine göre istatistiksel olarak anlamlı derecede düşük bulunmuştur $(p<0,001)$. Bunun başlıca nedeninin, ülkemizin $\mathrm{AB}$ ülkelerine göre daha fazla genç nüfusa sahip olması olduğu düşünülebilir. Ülkeler arasında ölüm hızlarına göre, istatistiksel karşılaştırma yaparken kaba ölüm hızı yerine yaş faktörünün farklılık üzerindeki etkisini ortadan kaldıran standart nüfus kullanımı esastır. Ancak standardizasyon için gerekli yaş gruplarına ulaşılamaması nedeniyle, bu çalışmada kaba ölüm hızları ile değerlendirme yoluna gidilmiştir. Her türlü sağlık hizmetinin dengeli, ulaşlabilir, sürekli, kaliteli ve en üst düzeyde verilmesinde en önemli etken, bütün sağlık hizmetlerinin hekimi, hemşiresi ve diğer sağlık çalışanları ile bir ekip hizmeti olarak verilmesidir. Avrupa Birliğini oluşturan ülkeler ile ülkemizin sağlık alanında çalışan insan gücünü değerlendirdiğimizde, hekim sayısı, ebe-hemşire sayısı ve kişi başına düşen yatak sayısı açısından ülkemizin istatistiksel olarak anlamlı düzeyde geride olduğu saptanmıştır $(p<0,001)$. Akman M.'nin çalışmasında, 2002 ile 2012 arasındaki 10 yıllık sürede yaklaşık 25 bin yeni uzman yetişirken, pratisyen hekim sayısındaki $\operatorname{artışın~} 8$ bin ile sınırlı olduğu gösterilmiştir. Aynı yıllarda uzman hekim /pratisyen hekim oranı 1,47'den 1,80'e yükselmiştir. Bu durum, 7 yılda birinci basamağın ayaktan poliklinik başvuruları içindeki payının sadece \%3,5 yükselmiş olması verisi ile tamamlandığında, 10 yıllık sağlıkta dönüşüm politikası sürecinde birinci basamağın iş gücü veya hasta başvurusunda aldığı pay açısından desteklenmediğini göstermektedir. ${ }^{14}$ yapılan çok sayıda doğumların da bu oranların yüksekliğinin önlenebilir nedenleri arasında olduğunu düşünülmektedir. ${ }^{10}$

Ülkemize ait 2013 yılı verileri ışı̆̆ında, anne ölüm hızının AB'ye üye ülkeler ortalamasından anlamlı şekilde yüksek olduğu belirlenmiştir $(p<0,001)$. Ancak Vehid'in yaptığ araştırmada, 1998 yılında ülkemizdeki anne ölüm hızının yüzbinde180 olarak bildirilmesine karşın, 2013 yılında bu değerin yüzbinde20'ye gerilediği saptanmıştır. ${ }^{11,12}$ AB üyesi olan Romanya'da bu değer yüzbinde 33, Letonya'da yüzbinde 20 düzeyindedir. $\mathrm{Bu}$ düşüşün başta birinci basamak hekimliğinin, aile hekimliği sisteminin ve bunun bir parçası olan ana- çocuk sağlığı hizmetlerinin yaygınlığı ve yeterliliğinin artması sonucunda oluştuğu tahmin öngörülebilir. ${ }^{7}{ }^{13}$ Doğum öncesi dönemde verilen $\mathrm{s}$ a $\breve{g} 1 \mathrm{k} \quad$ hizmetlerinin

Son yıllarda, sağlıkta dönüşüm politikası kapsamında yapılan eylem planı ile, sağlık insan gücünü sayısal olarak arttırmak için üniversitelerde tıp dahil sağlık bilimleri ile ilişkili fakültelerde öğrenci sayısını arttırmak, zorunlu hizmet uygulaması ile coğrafi olarak hekim dağılımında ki eşitsizliği ortadan kaldırmak ve performansa bağlı geri ödemelerle çalışanların verimliliğini arttırmak gibi uygulamalar yürürlüğe girmiştir. 14 Ülkemizdeki tıp fakültesi sayısının artması ile, gelecek yıllarda hekim sayısının artacağı ve $A B$ ortalamasına hızla yaklaşılacağı tahmin edilmekle beraber, fakültelerin eğitim kalitesinin $\mathrm{ve}$ mezuniyet sonrasi e ğitimin geliştirilmesi amacıyla çalışmalar yapılması önerilmektedir. Ülkemizin hemşire-ebe sayıları açısından $\mathrm{AB}$ ortalamasının çok altında olduğu saptanmıştır. Yataklı tedavi kurumlarındaki yatak sayıları değerlendirildiğinde, $\mathrm{AB}$ ortalamasından düşük olduğu görülmüştür. Bu sayının arttırılması amacıyla yeni sağlık merkezlerinin kurulması gerekliliğinin kaçınılmaz olduğu düşünülmektedir. 3,5 Bener ve ark. yaptığı çalışmada, on bin kişiye düşen yatak sayısı Almanya'da 83, Yunanistan'da 38 olarak belirtilmiştir. $\mathrm{Bu}$ oran ülkemiz için 25 'dir $^{15}$

Çalışmamızda dikkat çeken unsurlardan biri de, TUİK verileri ile DSÖ Türkiye verileri arasında ki farktır. TUİK verileri DSÖ verilerinden her ne kadar Avrupa birliği ortalamaları ile aralarında istatistiksel olarak benzer anlamlı fark olsa da, daha olumludur. ${ }^{10}$

Ülkemizde birinci basamak sağlık
hizmetlerinin erişiminin, sürekliliğinin,
koordinasyonunun ve finansmanının sağlanması,
sağlık sistemine birinci basamağın entegrasyonu
sistemin yetkinliğini arttıracaktır. ${ }^{16}$ Aile hekimliği


hizmetleri arasında yer alan bebek ve çocukların bağışıklanması ve gebe izlemlerinin daha titiz ve kontrollü yapılmasının yüksek olan bebek ölüm hızı, beş yaş altı ölüm hızı ve anne ölüm hızını düşüreceği değerlendirilmektedir. ${ }^{12,17}$ Diğer taraftan ülkemizde oldukça düşük olan kişi başı sağlık harcamasının arttırılması birinci basamak sağlık hizmetlerinin kalitesini arttıracak ve kişi başına düşen sağlı personeli sayısına da olumlu katkıda bulunacaktır.

\section{KAYNAKLAR}

1. Archick K. The European Union: Questions and Answers: Congressional Research Service Report; 2016. p.1.

2. First Nations Centre Understanding Health Indicators. Ottawa: National Aboriginal Health Organization; 2007. p.8.

3. Hayran O, Sur H. Sağlık Hizmetleri El Kitabı: Örgütlenme, Finansman, Yönetim, Mevzuat. Istanbul: Yüce Yayınları; 1998.p. 33-48.

4. World Health Statistics Indicators- Indicator Compendium. In: Indicator Code Book-World Health Statistics. WHO Press; 2015. http://who.int/gho/publications/World.health_st atistics/whs 2015 indicator compendium.pdf/ Erişim tarihi: 15/06/2016 p. 44-157.

5. World development indicators (WDI): Worldbank 2014. http://wdi.worldbank.org/table/2.21.2014/ Erişim tarihi:07/06/2016

6. World Health Organization (WHO). Global Health Indicators. In: World Health Statistics. Geneva: WHO Press; 2014. http://www.who.int/gho/publications/world he alth_statistics/EN-WHS2014_pdf/

Erişim tarihi:10/06/2016 p.59-151.

7. World Health Organization (WHO). Global Health Indicators. In: World Health Statistics. Geneva: WHO Press; 2015.p.4377.http://www.who.int/gho/publications/world _health_statistics/EN-WHS2015_Part2.pdf/ Erişim tarihi:10/06/2016 p.44-157.
8. Wordlow T. Statistical tables. In: Aslam A, editor. The State of the World's Children. New York: United Nations Children's Fund (UNICEF); January, 2014.p.30-89.

9. Statistical tables. In: The State of the World's Children. New York: United Nations Children's Fund (UNICEF); January, 2015. p. 36-83.

10. TUİK Sağlık araştırması 2012. Ankara p. 1. http://www.tuik.gov.tr/Kitap. do?metod=KitapDetay\&KT_ID=1\&KITAP_I $\mathrm{D}=223$ / Erişim tarihi: 28/08/2016

11. TC Sağlık Bakanlığ Sağlık İstatistikleri Yıllığ 2013.

http://sbu.saglik.gov.tr/Ekutuphane/kitaplar/ista turk2013.pdf/ Erişim tarihi:01/05/2016 p.1418.

12. Vehid S. Temel demografik ve sağlık düzeyi ölçütleri açısından Türkiye ile Avrupa Birliği ülkelerinin karşılaştırılması. Cerrahpasa J Med 2000; 31 (2): 100-106.

13. OECD Health Data 2015. http://stats.oecd.org/BrandedView.aspx?oecd bv_id=health-data-en\&doi=data-00542-en/ Erişim tarihi: 08/06/2016

14. Akman M. Türkiye'de birinci basamağın gücü. Türk Aile Hek Derg 2013;17(4):165-179.

15. Bener A, Mazroi AA. Health services management in Qatar. Croat Medical Journal 2010; 51: 85-8.

16. Kringos DS. The importance of measuring and improving the strength of primary care in Europe: results of an international comparative study. Türk Aile Hek Derg 2013;17(4):165179.

17. Yüceokur AA. Ana-çocuk sağlığı ve aile planlaması. Baltaş Z, editör. Halk Sağlığı Ders Kitab1, 1.Bask1. Istanbul: Istanbul Üniversitesi, Cerrahpaşa Tıp Fakültesi yayınlar1; 2008. p. 739-761. 